\title{
認知症高齢者への食事支援
}

\author{
浅川典子
}

(埼玉医科大学保健医療学部看護学科)

\section{Offering help to the elderlies with dementia taking meals}

\author{
Noriko Asakawa \\ School of Nursing, Faculty of Health and Medical Care, Saitama Medical University, \\ 1397-1, Yamane, Hidaka-shi, Saitama, 350-1241 \\ テ350-1241＼cjkstart埼玉県日高市山根1397-1
}

\begin{abstract}
Symptoms of dementia are divided into two major categories of core symptoms and secondary symptoms (BPSD). Core symptoms consist of cognitive function disorders such as memory impairment, orientation disorder, disturbance of execution function, poor comprehension and poor judgment, aphasia, apraxia and agnosia. These are inevitable symptoms brought about by organic changes in the brain. Taking meals is one of the important daily activities enjoyed by the elderlies. Some elderlies, however, refuse to eat when meals are taken to them and refuse to drink when a glass of water is offered to them. They even refuse to open their mouth when people talk to them and offer help. Or, they may just simply stop taking meals and refuse to use chopsticks. Some elderlies continue to pretend as if they are eating even when there is no food left. In such instances, urging the elderlies to stop their behavior or forcing them to behave in a certain way is not effective. Taking into account that such behavior is caused by core symptoms of the disease, it is necessary to explore ways to assist the elderlies taking meals by making maximum use of what is left of their ability, without leading them into confusion.
\end{abstract}

\section{1.はじめに}

全国認知症者有病率調査によれば，認知症有病者数は 約 439 万人, 65 歳以上高歯者の認知症有病率は約 $15 \%$ と 報告されている ${ }^{1)}$ 。今後，高齢者人口の増加とともに認 知症高齢者の一層の増加が見込まれている。

認知症は，1970年代に出版された有吉佐和子の『恍惚 の人』により，ぼ老人（痴呆老人）として社会問題と して認識されることとなった。当時は, 認知症の人は「何 もわからなくなった人」というイメージで捉えられてお り, その原因や対応方法もわからないために, 最低限の 身体介護や問題行動の抑制に焦点をあてたケアがなされ ることが多かった2)。

近年では, 認知症は神経変性疾患, 脳血管障害, 感染 症などさまざまな機序の大脳の障害により発症すること が知られており, 画像診断の発展による診断精度の向上 により症状についての症候学的理解も進んでいる。そし
て, アルッハイマー型認知症, 血管性認知症, レビー小 体型認知症，前頭側頭型認知症などの主な認知症につい ては，診断別に病気の特徴が明らかにされている ${ }^{3)} 。$

また，早期診断が進むにつれて，認知症と診断された 人自身が体験を語ったり，手記を出版したりするなど, 本人の視点に立った理解と支援を求める動きが活発に なっている。最近では, 認知症の人のケアにあたっては, その人の視点に立ち, その人が体験している世界を理解 しょうとする姿勢が不可欠である ${ }^{4)}$ との認識が広まって いる。

\section{2. 認知症の症状}

認知症の症状は，中核症状と周辺症状 (BPSD) に大 別される。中核症状とは, 記憶障害, 見当識障害, 実行 機能障害, 理解 - 判断力の低下, 失語, 失行, 失認など の認知機能障害のことであり, 脳の器質的障害によって 必然的に生じる症状である ${ }^{5)}$ 。中核症状に対する治療薬 
の開発が進んで抢り進行を遅らせる効果が期待されてい るが, 根治作用はない。認知機能障害が進行すると, 日 常生活を上手く営むことが難しくなるので，認知症高齢 者の持てる力を引き出していくための周囲の人の対応や かかわりの工夫がとても重要となる。

周辺症状は, 中核症状の進行に伴い出現する行動異常 および心理症状のことである。近年では, 認知症の行動・ 心理症状 (Behavioral and Psychological Symptoms of Dementia; BPSD）と表わされることが多い。具体的には， 攻撃性，不穏，焦燥性興奮，脱抑制，収集癖，異食，不 安，うつ症状，幻覚，妄想などの症状である。BPSD は 周囲の人の不適切な対応やケア，環境，身体合併症など により増強する ${ }^{5)}$ 。治療としては向精神病薬が用いられ ているが, 『BPSDに対応する向精神病薬使用ガイドラ イン (厚生労働省，2013年)』 に第一選択は非薬物療法 であると明記されているように，薬によらないかかわり も試みる必要があるとの認識が広まっている。

\section{3．中核症状の進行による生活の難しさ}

認知機能障害が進行すると，日常生活をそれまで通り に営むことが難しくなる。そのため，何ができて何がで きないのかを具体的に把握し，できない部分を補うケア が必要となるが，その時に重要となるのは，以下のよう

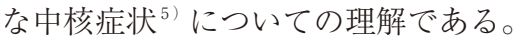

\section{【記憶障害】}

記憶の働きは新しい情報を覚える（記銘），記銘した 情報を蓄える（保持），保持している情報を思い出す（想 起)である。情報の保持時間により短期記憶（即時記憶 近時記憶）と長期記憶（遠隔記憶）に区分される。短期 記憶の障害により新しい情報を覚えることができないと， 経験したばかりの出来事を思い出せなくなる。認知症が 進行すると，長期記憶として蓄えられている昔のことも 思い出せなくなる。

また，記憶は内容によりエピソード記憶（個人的な経 験の記憶), 意味記憶 (知識), 手続き記憶 (身体で覚え た技能）に区分される。エピソード記憶は障害されやす く，手続き記憶は障害されにくい。

【見当識障害】

見当識とは時間・場所・人の見当をつけ自分の状況を 理解する能力である。見当識障害は時間, 場所, 人の順 に進行する。見当識障害が進行すると, 周囲の状況と自 分自身の状況に関する正確な把握が困難になる。そのた め, 自分が誰で，今，どこで何をしているのかという基 本的な自己の認識が混乱する。

\section{【実行機能障害】}

実行機能とは，立案した計画を必要に応じて修正しな がら, 効率的に遂行していく能力である。実行機能が障 害されると状況を的確に分析し，状況に合った手順を計 画し物事を行っていくことが難しくなる。そのため, 仕 事や家事の手順が悪く非効率的となったり，変化に対す
る柔軟な対応もできなくなったりする。

【理解力・判断力の低下】

理解力の低下の初期には，考えるスピードが遅くなっ たり，複数の出来事が重なると上手く処理できなくなっ たりする。進行すると，「今，ここで起きていること」 を理解することが難しくなり，日常生活が大きく混乱す る。

\section{【失 語】}

失語とは，思考や概念を言語に置き換えることや，言 葉の意味を理解することが難しくなる障害である。言葉 の想起がしにくく，話そうとした内容を忘れてしまうこ とが多くなり，普通の会話についていけなくなる。また， 文脈を理解しないままの場合わせ的な返答も多くなる。

\section{【失 行】}

失行とは，身体の運動機能は保たれているが，特定の 動作を遂行することができなくなる障害である。自然な 場面でできる習慣的な単純な動作が命じられるとできな かったり，いくつかの連続した動作が必要な場合に順序 が混乱して行為を遂行することができなかったりする。

【失 認】

失認とは，感覚機能は保たれているにもかかわらず, 視覚，聴覚などを介して対象を認知することの障害であ る。視覚失認があると，よく知っている人や物でも見る だけでは認識できなくなる。

\section{4. 中核症状による食行動の混乱}

食べることは生命維持と活動の源であり，高齢者に とっては日常生活に扔ける最も大きな楽しみである。し かし，認知症の中核症状が進行することによりさまざま な影響が現れる7

食べること（摂食・曣下）は先行期，準備期，口腔期， 咽頭期, 食道期の 5 期に分類される。その中で最も認知 症の影響を受けるのは先行期である。先行期は食物を理 解し口に入れるまでの時期であり，認知期ともよばれる。 実際に食物を口まで運ぶ動作も含まれるが，何をどのく らい，どんな風に食べるかを決定する時期である。

中核症状である記憶障害，見当識障害，実行機能障害， 理解・判断力の低下, 失語, 失行, 失認などの認知機能 障害の進行は認知症の病名や重症度によって異なるが, 病気の進行に伴い配膳しても食べ始めない, コップに 入っている水を飲まない, 蓋つきの器に入っている物を 食べない，ご飯が残っているのに食べない，箬を使挹う としない，食物が残っていないのに食事動作を続けよう とする，プリンを箸で食べようとする，スプーンを逆さ に持ちすく㧈うとする，早食いなのでゆっくり食べるよ う促すと「はい」と返事はするが食べ方が変わらない, 他の人の扮やつを食べてしまうなどの症状がみられるこ とがある。

そのような症状に対してのむやみな行動の促しや制止 は効果的でなく，混乱を増長することとなりやすい。認 
知症高齢者が食事を開始することができなかったり，上 手く食具を用いることができなかったり，他の人の食事 を食べようとしたりする原因は, 病気の中核症状である 実行機能障害, 失認, 失行, 理解力・判断力の低下など にあるので，それらの症状について，まず中核症状の視 点から食行動の混乱を理解し，それを踏まえて支援方法 を検討することが大切である。

同様に，食事を途中で中断してしまったり，食事中に 近くにいると話しかけられてしまい食事が進まなかった りするのは注意力の低下，食事介助のときに声かけする と口を開かないのは口腔顔面失行, 食べ終わったばかり なのに「まだ食べていない」と言うのは記憶障害などと いうように，認知症高齢者の食事場面で観察されるさま ざまな食行動の混乱について, 認知症の中核症状の視点 から理解することが重要である。その上で, 認知機能の 障害に合わせた具体的な支援方法を検討していくことが 必要となる。

\section{5. 認知症高齢者の食事支援で大切なこと}

認知症の人への対応の基本として，「間違えたことを 注意しない」「命令しない（指示しない）」「理屈による 説得よりも共感的な納得」が大切であることは広く知ら れるようになってきている。それは, 認知症の人の日常
生活の混乱は, 中核症状の進行のために引き起こされて いるからである。

認知症の人のケアにあたっては，その人の視点に立ち, その人が体験している世界を理解しようとする姿勢が不 可欠であるとされている。食事支援に打いても，食行動 の混乱は中核症状である認知機能の障害により引き起こ されていることを理解し, 場面の詳細な観察を通して, 残されている力で混乱せず食べられる支援方法の探索が 必要となる。

\section{文 献}

1）厚生労働統計協会：国民の福祉と介護の動向・厚生の指 標 増刊, 61(10)，175-178 (2014)

2）加藤伸司, 加藤伸司：認知症ケアはここまで進んだ, 老 年精神医学雑誌, 19(6)，629-635（2008）

3 ）池田学編集：DSM-5 を読及解く, 中山書店, 東京, pp.41-78 (2014)

4) 長谷川和夫：認知症の医療とケア 今とこれから, 早期 認知症学会誌, 7(1), 6-10 (2014)

5）斎藤正彦：チームアプローチのための老年期精神医学, 新興医学出版社, 東京, pp.70-131 (2007)

6）厚生労働省：「かかりつけ医のためのBPSD に対応する向 精神病薬使用ガイドライン」について, www.mhlw.go.jp/ stf/houdou/2r98520000036k0c.html

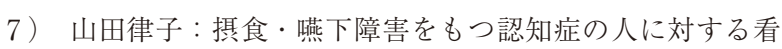
護の実際，老年精神医学雑誌，20，1377-1386

本稿は, 第51回研究集会における発題講演をまとめたものである。 